\title{
A Review of Macrodystrophia Lipomatosa: Revisitation
}

\author{
Theddeus OH Prasetyono, Enjeline Hanafi*, Windi Astriana* \\ Division of Plastic Surgery, Department of Surgery, Cipto Mangunkusumo Hospital/Faculty of Medicine, University of Indonesia, Jakarta, \\ Indonesia
}

Macrodystrophia lipomatosa (MDL) is a rare congenital non-hereditary disorder that has significant impact on patient morbidity. This study provides a comprehensive review of the natural history, diagnosis, management, and outcomes of the disorder. A literature search in PubMed was conducted to identify cases of MDL from January 1950 to 14 February 2014. After ruling out articles without information related to the management of the disorder, a summary of 32 studies was performed. An additional three cases from the authors are also presented. Based on 57 journal articles and three additional cases from the authors, around 108 cases of MDL were reviewed. Most patients were males who were admitted to a treatment clinic in the first four years of life. The lower extremities were more frequently affected, with unilateral presentation being most common. They commonly underwent a single-staged surgical procedure with follow-up periods ranging from more than one year up to 21 years. Out of 43 cases that underwent surgical procedures, 13 reported no complications, and there were seven cases of esthetic satisfaction and 15 cases of significant functional improvement. Depending on the severity of a patient's condition, the use of non-invasive diagnostic tools should be carefully considered. Surgery might be a better choice of management than observation, taking into account possible future complications in the absence of surgery and the beneficial outcomes of surgical procedures.

Keywords Congenital limb deformities / Fingers / Lower extremity / Upper extremity

\author{
Correspondence: \\ Theddeus $\mathrm{OH}$ Prasetyono \\ Division of Plastic Surgery, \\ Department of Surgery, \\ Cipto Mangunkusumo Hospital/ \\ Faculty of Medicine, University of \\ Indonesia, Medical Staff Building 4th \\ Floor, Jl. Diponegoro 71 Jakarta 13410, \\ Indonesia \\ Tel: $+62-817858899$ \\ Fax: +62-21-31903152 \\ E-mail: teddyohprasetyono@yahoo. \\ com
}

*Research assistant to the first author

This article contains Appendices 1-4.

No potential conflict of interest relevant to this article was reported.

\section{INTRODUCTION}

Macrodystrophia lipomatosa (MDL) is a rare congenital nonhereditary disorder in which a disproportionate overgrowth of fibroadipose tissue manifests as gigantism of a small part or the whole of an extremity(-ies). It causes significant functional and esthetic problems for patients and families. Although its impact on the well-being of patients is significant, not much is known about this disorder. A systematic review of more than 100 studies by Tahiri et al. [1] discussed the diagnostic approaches and management of 180 cases of MDL. However, the summary could be considered inadequate, because the cases reported were only those involving the median nerve.

In addition to the invasive gold standard of histopathological examination, other non-invasive examinations could help diagnose MDL. Both surgical and non-surgical approaches can be used in the management of MDL, with varying complications and outcomes in different cases [2,3].

To our knowledge, there is currently no study that provides comprehensive guidance on how to diagnose and manage pa- 
tients with MDL. The present study provides a comprehensive summary of the disorder in a review format. Furthermore, discussion of diagnosis and management choices of the given cases is included to provide better understanding of the results of the review.

\section{METHODS}

A literature search in PubMed was conducted to identify cases of MDL from January 1950 to 14 February, 2014. MDL and macrodactyly were used as the search terms. Studies that fulfilled the inclusion and exclusion criteria were included. The inclusion criterion was all case series and case reports with the diagnosis of MDL. Exclusion criteria were articles with systematic review and literature review, as well as letters to editors. The abstract and full text of each article were obtained and screened by two independent reviewers (E.H. and W.A.). Duplication of cases was prevented by repeated matching by the authors.

An initial literature search revealed a total of 73 articles. Articles without information related to the management of the disorder were excluded, after which a total of 32 studies was obtained that was further appraised by using forms adapted from the Center for Evidence-Based Management [4].

Additionally, a case series of three patients who were enrolled at our hospital unit between January 2013 and December 2013 is also presented in this study. These cases are included in the summary.

Details, such as age, gender, anatomical location and size of affected areas, diagnostic tools used, management, length of fol- low-up, post-surgery complications, and outcomes were collected as basic data. The data was then simplified into several tables.

Age was defined as the age of the first presentation to the hospital due to MDL. Anatomical location was categorized as unilateral or bilateral and which part(s) of the anatomical area was affected. Management of MDL was divided into surgical (multistaged, single-staged, or unspecified) and non-surgical. Unspecified surgery was categorized as unspecified when the article did not provide enough information for us to decide, and observation was not a part of this category. Non-surgical management consisted of on-demand and intentional observation. Length of follow-up was defined as the period of time after the first management was implemented until the last time the patient presented for assessment. Post-surgical complication(s) were defined as any mild or severe event related to the affected area after surgery. Finally, outcomes were divided into esthetic and functional. While esthetic outcome is defined subjectively by the patient or parent, the functional outcome is decided objectively by doctors or authors. Significant and fair functional improvements differed in how the surgery affected the patient's daily function. If the surgery had a strong positive impact on the patient's daily activity, improvement was classified as significant. If the changes only had a mild impact, improvement was defined as fair. Improvement was defined as unspecified when there was no information on the function of the affected extremity prior to the surgery.

\section{RESULTS}

There were a total of 108 cases of MDL identified from both the Table 1. Characteristics of patients in the authors' unit

\begin{tabular}{|c|c|c|c|c|c|c|c|c|c|c|}
\hline \multirow{2}{*}{ No. } & \multirow{2}{*}{$\begin{array}{l}\text { Age } \\
(\mathrm{yr})\end{array}$} & \multirow{2}{*}{ Gender } & \multirow{2}{*}{$\begin{array}{l}\text { Length of } \\
\text { follow-up } \\
\quad(\mathrm{mo})\end{array}$} & \multirow{2}{*}{$\begin{array}{l}\text { Anatomical } \\
\text { Location }\end{array}$} & \multirow{2}{*}{ Size } & \multirow{2}{*}{$\begin{array}{l}\text { Diagnostic } \\
\text { tools }\end{array}$} & \multirow{2}{*}{ Management } & \multirow{2}{*}{$\begin{array}{l}\text { Compli- } \\
\text { cations }\end{array}$} & \multicolumn{2}{|c|}{ Outcome } \\
\hline & & & & & & & & & Esthetic & Functional \\
\hline 1 & 18 & Male & 14 & $\begin{array}{l}\text { Calcaneal and } \\
\text { Achilles area } \\
\text { of the right } \\
\text { foot }\end{array}$ & $\begin{array}{l}\text { Right foot shoe size } \\
\text { was three sizes } \\
\text { higher than the left }\end{array}$ & MRI & $\begin{array}{l}\text { Childhood: amputation } \\
\text { of 4th and 5th toes. } \\
\text { At } 18 \mathrm{yr} \text { : mass } \\
\text { reduction }\end{array}$ & $\mathrm{N} / \mathrm{A}$ & Satisfactory & $\begin{array}{l}\text { Significant } \\
\text { improvement }\end{array}$ \\
\hline 2 & 6 & Female & 3 & $\begin{array}{l}\text { Second, third, } \\
\text { and fourth } \\
\text { toes of the } \\
\text { left foot }\end{array}$ & $\begin{array}{l}\text { Metatarsal head-to- } \\
\text { head size was } \\
\text { double that of the } \\
\text { normal right foot; } \\
\text { third toe was six } \\
\text { times the normal } \\
\text { length and } \\
\text { circumference }\end{array}$ & MRI & $\begin{array}{l}\text { Central ray amputation } \\
\text { and soft tissue and } \\
\text { bone reduction of the } \\
\text { second and fourth } \\
\text { rays }\end{array}$ & $\begin{array}{l}\text { Delayed wound } \\
\text { healing; } \\
\text { healed by skin } \\
\text { graft }\end{array}$ & Satisfactory & Fair improvement \\
\hline 3 & $14 \mathrm{mo}$ & Male & 2 & $\begin{array}{l}\text { Thumb, index, } \\
\text { and thenar } \\
\text { area of the } \\
\text { right hand }\end{array}$ & $\begin{array}{l}\text { Circumferences were } \\
\text { three and four } \\
\text { times higher than } \\
\text { normal }\end{array}$ & $\begin{array}{l}\text { Plain } \\
\text { radiography }\end{array}$ & $\begin{array}{l}\text { Staged mass reduction } \\
\text { and joint } \\
\text { reconstruction } \\
\text { separated by six- } \\
\text { month interval }\end{array}$ & $\mathrm{N} / \mathrm{A}$ & Satisfactory & Fair improvement \\
\hline
\end{tabular}


57 journal articles obtained from the literature search combined with the three additional cases from the authors. Among these cases, only 43 journal articles contained information about clinical management of MDL. With the addition of three cases from the authors, there were 46 cases that could be reviewed. A summary of these all-inclusive studies is provided in the Appendices (Appendices 1,2). The details of the three additional MDL cases can be seen in Table 1.

Table 2 [5] describes the clinical characteristics of all the cases, including three cases from the authors. Twenty-three percent of patients admitted were children, particularly in the first four years of life; more than half of the patients were male. Out of 46 patients, 28 underwent a single-staged surgical procedure, 11 had multi-staged surgery, and four patients went through unspecified surgery. Only three patients with two unilateral cases and one bilateral case were under observation alone. Among the 46 cases, only one indicated bilateral involvement, specifically in the upper extremities. The treatment was different for each side in this case; the left side underwent surgery, while the right side was only observed.

The length of follow-up was not provided by most articles. From the available information on follow-up, only nine patients were monitored up to one year, while 13 patients were followed-

\begin{tabular}{|c|c|c|c|}
\hline Characteristic & $\begin{array}{l}\text { Reported with } \\
\text { management } \\
(n=46)\end{array}$ & $\begin{array}{l}\text { Reported } \\
\text { without } \\
\text { management } \\
(n=62)\end{array}$ & $\begin{array}{c}\text { Total } \\
(n=108)\end{array}$ \\
\hline \multicolumn{4}{|c|}{ Age on admission (yr) } \\
\hline $0-4$ & $19(41.3)$ & $6(9.7)$ & $25(23.1)$ \\
\hline $5-9$ & $5(10.9)$ & 8 (12.9) & $13(12.0)$ \\
\hline $10-19$ & $6(13.0)$ & $4(6.5)$ & $10(9.3)$ \\
\hline $20-29$ & $5(10.9)$ & 0 & $5(4.6)$ \\
\hline $30-39$ & $2(4.3)$ & $3(4.8)$ & $5(4.6)$ \\
\hline $40-49$ & 5 (10.9) & $4(6.5)$ & $9(8.3)$ \\
\hline$\geq 50$ & $3(6.5)$ & 0 & $3(2.8)$ \\
\hline No data & $4(8.7)$ & $34(54.8)$ & $38(3.5)$ \\
\hline \multicolumn{4}{|l|}{ Gender } \\
\hline Male & $31(67.4)$ & 27 (43.5) & $58(53.7)$ \\
\hline Female & 15 (32.6) & $24(38.7)$ & 39 (36.1) \\
\hline No data & 0 & $11(10.2)$ & $11(10.2)$ \\
\hline \multicolumn{4}{|l|}{ Management } \\
\hline \multicolumn{4}{|l|}{ Surgical } \\
\hline Single & 28 & & \\
\hline Multiple & 11 & & \\
\hline Unspecified & 4 & & \\
\hline Non-surgical|a) & 4 & & \\
\hline \multicolumn{4}{|c|}{ Length of follow-up (yr) } \\
\hline $0-1$ & 9 & & \\
\hline$>1-20$ & 12 & & \\
\hline$\geq 21^{\text {a) }}$ & $3^{\text {a) }}$ & & \\
\hline No data & 22 & & \\
\hline \multicolumn{4}{|c|}{$\begin{array}{l}\text { Values are presented as number of cases (\%). } \\
\text { a)Bilateral case patient [5]. }\end{array}$} \\
\hline
\end{tabular}

up for periods ranging from more than one year up to 21 years. A length of follow-up for more than 21 years occurred in only two patients. After surgery, most patients reported no significant complications and good esthetic and functional outcomes. The unavailability of such data, however, is around 50\% among all patients who had surgery. In the patient with bilateral involvement, the operated extremity was performing better functionally compared to the non-operated extremity.

The review also shows that almost $60 \%$ of the cases involved the lower extremity (Table 3). The hand and foot were found to be common sites of MDL, with percentages of 54.1\% and 64.4\%, respectively. MDL affects upper limbs in $31.7 \%$ of cases and $5.1 \%$ in lower limbs only.

There are several characteristics that describe patients who undergo surgical and non-surgical treatment. A patient could have an amputation if there are severe functional and esthetic disturbances due to MDL. Debulking or reduction is usually performed if nerve and tendon preservation are planned in addition to esthetic preservation. Other types of surgery are performed depending on the condition of the patient. On the other hand, non-surgical cases are divided into observation on demand and intentional observation. Observation on demand occurs in patients who refused surgical treatment, while intentional observation is chosen in the presence of other urgent medical conditions or as decided by the physicians. Local single-digit involvement is said to be an indication for observation due to the principle of digit preservation in reconstruction.

Different radiographic tools are utilized in MDL. Plain radiography (X-ray) can detect any abnormalities in bone, soft tissues, and joints. Magnetic resonance imaging (MRI) can show fat tissue predominance and the condition of nerves and their sheaths. Computed tomography (CT) scans are used to detect proliferation of fat with bone overgrowth. Ultrasonography can be performed to detect any calcification and abnormal blood flow. There are also other additional examinations, such as nerve conduction tests and electromyography that are performed as necessary.

\section{Table 3. Affected areas in patients with macrodystrophia} lipomatosa

\begin{tabular}{|lc|}
\hline Value & No. of cases (\%) \\
\hline Upper extremities $(\mathrm{n}=41)$ & \\
Upper extremities & $13(31.7)$ \\
Hand only & $23(56.1)$ \\
Unspecified & $5(12.2)$ \\
Lower extremities $(\mathrm{n}=59)$ & \\
Lower extremities & $3(5.1)$ \\
Foot only & $38(64.4)$ \\
Unspecified & $18(30.5)$ \\
\hline
\end{tabular}




\section{DISCUSSION}

About 89 years after its first report [6], MDL has become widely known as a disorder of proliferation of mesenchymal and adipose tissue. The affected area grows in a normal pattern or much faster than the unaffected area, causing a gigantic disproportional appearance [7]. In recent years, there have been few articles describing cases diagnosed as MDL.

In this study, we found that the admission with MDL occurs primarily before the age of four. Problems start to surface with the growth of the child. Toddlers are reported to have difficulty in wearing shoes and to sustain repeated injuries, which may affect their daily activities, especially their learning development, social interaction, and self-confidence [2]. Secondary functional problems, such as secondary osteoarthritis and compression of neurovascular elements, usually arise when the patients are older [8]. This is why some patients first present at a later age. Esthetic problems, on the other hand, can begin at any age $[2,8$ 11]. Patients or their parents seek treatment typically due to the cosmetic appearance of the affected area, although functional reasons also play an important role.

MDL can be categorized into static and progressive types. In static MDL, the affected area grows proportionately, while in progressive MDL, disproportionate growth occurs [12]. Some studies have postulated that the growth of the affected area may slow down or cease if patients have finished their growth spurts $[8,10,13]$. This idea, however, seems more likely to apply to the static type of MDL. As the rest of the body ends its growth, the growth of the affected area may stop as well.

MDL has no gender predominance [14-16]. The difference in the number of males and females with MDL in this study are too insignificant to be considered as predominance. Our study also found that unilateral distribution is common, because bilateral distribution only occurred in three cases. Hand or foot involvement is more common than whole extremities. Specifically, there is a high possibility for the first, second and third digits of the hand or foot to be involved singularly or adjacently. The combination of the second and third digits has the highest frequency (Table 4) [17-20].

The findings may be related to the theory that MDL manifests according to the distribution of the sclerotome [21]; this is a group of mesenchymal cells that gives rise to the skeletal tissue of the body and develops into the vertebrae and ribs [22]. As the little finger is rarely affected (Appendices 3, 4), it is also possible that the distribution is based on the median or plantar nerve innervations.

The diagnosis of MDL is made through clinical presentation and radiographic examination. Many modalities have been re-

\begin{tabular}{|c|c|c|c|c|}
\hline Value & Hand & Foot & $\begin{array}{c}\text { Unspecified } \\
\text { extremity }\end{array}$ & Total \\
\hline One digit only & 10 & 16 & 2 & 28 \\
\hline 1st and 2nd digit & 5 & 1 & 3 & 9 \\
\hline 2nd and 3rd digit & 3 & 6 & 7 & 16 \\
\hline 3rd and 4th digit & $1^{\text {a) }}$ & 0 & 2 & 3 \\
\hline 4th and 5th digit & $2^{\text {a) }}$ & 1 & 0 & 3 \\
\hline 1st, 2nd, and 3rd digit & 2 & 4 & 1 & 7 \\
\hline 2nd, 3rd, and 4th digit & 1 & 5 & 2 & 8 \\
\hline 3rd, 4th, and 5th digit & 0 & 0 & 1 & 1 \\
\hline 1st, 2nd, 3rd, and 4th digit & 0 & 1 & 1 & 2 \\
\hline 2nd, 3rd, 4th, and 5th digit & 0 & 0 & 3 & 3 \\
\hline 1st, 2nd, 3rd, 4th, and 5th digit & 0 & 0 & 1 & 1 \\
\hline Unspecified digit(s) & $12^{b)}$ & $7^{\text {c) }}$ & 0 & 19 \\
\hline Total & 36 & 41 & 23 & 100 \\
\hline
\end{tabular}

ported to act as adjuncts in confirming the diagnosis, providing histopathological examination could not be performed $[11,13,15]$. Basic radiographic modalities that have widely been used are Xray [23-26], MRI [10,16,27-31], CT scan [11,14,32,33], and ultrasonography $[2,14,33,34]$. Additional examinations, such as nerve conduction tests and electromyography $[27,35]$, may also be performed. In fact, X-ray alone might be sufficient to diagnose MDL. This idea is supported by the presence of cases that used radiography as the single diagnostic tool, including one case from the author. If the extent of the disorder is unclear, or the composition of the macrodactyly tissue is doubtful, an MRI may be performed. Nonetheless, choices of diagnostic modality are made according to the clinical features, the availability of the modality and the goal of the examination.

As discussed previously, the management of MDL depends on age, clinical manifestation, and the extent of the disorder $[2,8,36]$. It can be divided into non-surgery and surgery. The decision regarding frequency of follow-up observation generally lies with the patients or parents, and with the physicians. Two types of observation are stated: observation on demand and intentional observation. The first type is determined by the patients or parents, while the latter might be led by the physicians. The benefits of observation are still unknown. However, there might be a lower recurrence rate once the patients have had surgery. In the bilaterally affected case report, there was an example of a worse outcome that was related to the decision of observation [5]. The follow-up duration of 42 years resulted in an unspecified functional outcome for the operated limb and a reduced functional outcome for the non-operated limb. The reason behind these 
observations was not discussed in the study. Considering the occurrence of such an outcome, it might have been better if the patient had had surgery on both extremities. A suggestion by the first author is that the right non-operated limb should undergo amputations of the third and fourth rays with an additional approach to the little finger, so that the patient could maintain his right hand grasp function. Overall, there is not enough strong evidence to support non-surgical management of MDL.

Surgery is more preferable than non-surgery to manage MDL $[5,36]$. The type of surgery often performed is amputation, followed by debulking or reduction. These are mostly executed in single-staged surgery. Multi-staged surgery usually occurs in more complex cases with a longer duration of follow-up. This could involve epiphysiodesis, osteotomy, and carpal tunnel release. Epiphysiodesis and osteotomy are performed with an objective to halt the growth of the abnormal limb and correct the deformities caused by disproportionate growth $[34,37]$. Carpal tunnel release is only performed when the patient complains of pain of the affected area.

Many patients underwent single-staged surgery in this study. It is important to note that these cases might have no follow-up data available, because many of them were presented as case reports or case series. The patients might or might not have presented for subsequent surgery in the future. Despite this, the length of follow-up in this study can be regarded as acceptable, as it covers more than a year. This time may be adequate for complications, both early and late, to surface. Some complications are loss of sensation, under-correction, and skin blackening [2, $9,27]$. Loss of sensation can result from the damage from extensive lesions, which need extensive surgery. The risk of complication after extensive surgery is about $30 \%-50 \%$ for nerve injury, and 33\%-60\% for recurrence of MDL $[8,11]$. Our study could not actually give the rate of recurrence of $\mathrm{MDL}$ due to the variety of patients' baseline characteristics and different rate of follow-up. Under-correction usually happens when there is an underestimation of the lesion dimension; this can be corrected readily. Skin blackening is caused by injury to the digital arteries [2]. A cautious approach during surgery and proper wound treatment are essential to prevent this. In order to ensure fewer complications, it is reported that ray removal might be a better choice [8]. If in the planning stage it is predicted that the function of the affected limb could not be preserved or that the digit may not function well despite its preservation, then ray amputation could be performed to prevent further complication, such as nerve entrapment, in the future. A suitable example can be observed in the second case given (Fig. 1).

Esthetic outcomes, as mentioned earlier, play an important part in the evaluation of surgery outcomes $[10,11]$. The satisfaction from the patients or parents may be higher than the physicians' expectation. Drastic changes in the size and shape of the affected area may give an impression that any reduced appearance of the area is good enough. In contrast, significant improvement in functional outcome can be hard to achieve. Retention of the function of the extremity, as well as procurement of appropriate function, depends solely on the surgery process and the severity of the disorder prior to surgery. An algorithm is proposed to guide physicians, who have more limited resources in dealing with MDL in particular (Fig. 2).

In this review, three additional cases are also given (Table 1). The cases consist of two males and one female patient aged 18 years, 14 months, and 6 years, respectively. The age distribution is older than in the other studies; however, the first case had had

\section{Fig. 1. Presentation of patient no. 2 in the unit}

A 6-year-old female presented with a metatarsal head-to-head size that was double that of the normal right foot; her third toe was six times the normal length and circumference $(A, B)$. X-ray indicated an enlargement of the second, third, and fourth digits $(C, D)$.
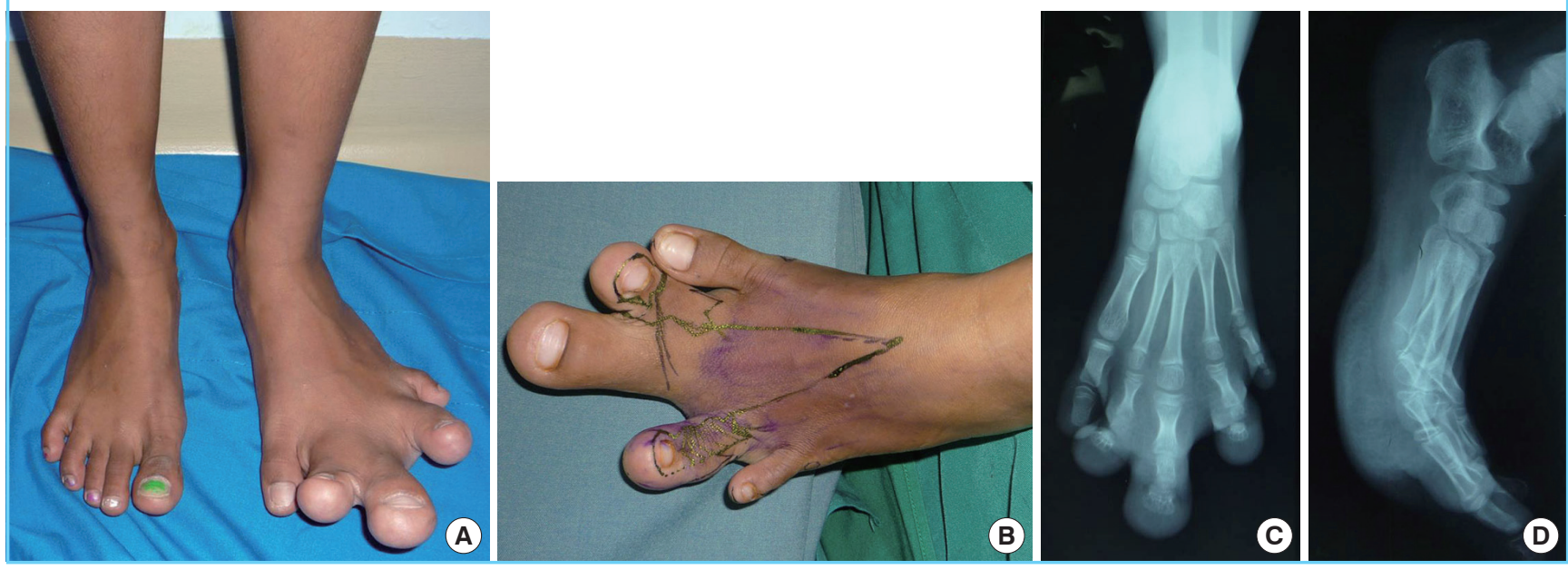


\section{Fig. 2. Algorithm for management of macrodystrophia lipomatosa}

This algorithm shows how to manage macrodystrophia lipomatosa (MDL) patients from early consultation to definitive management. Presentations of macrodactyly or megalodactyly should be accompanied by precise anamnesis. It should be asked whether the condition is painful or painless and if it is congenital and/or hereditary. Detailed physical examination should focus on the anatomical location, nature of the physical deformity, tenderness, dimensions of the affected area, and functional disturbances. At the least, X-ray should be performed as a diagnostic test, with further imaging tests performed if necessary and available. When the diagnosis of macrodystrophia lipomatosa is confirmed, management strategies comprise observation only or surgery followed by observation. Presentation of macrodystrophia lipomatosa before puberty, or with single digit involvement, or with concurrent urgent medical conditions calls for observation only. If these conditions are absent, surgery can be performed with subsequent observation for outcome and recurrence. EMG, electromyography; $\mathrm{CT}$, computed tomography; MRI, magnetic resonance imaging; USG,

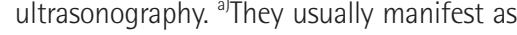
macrodactyly without adipose tissue overgrowth; ${ }^{b}$ Both esthetic and functional.

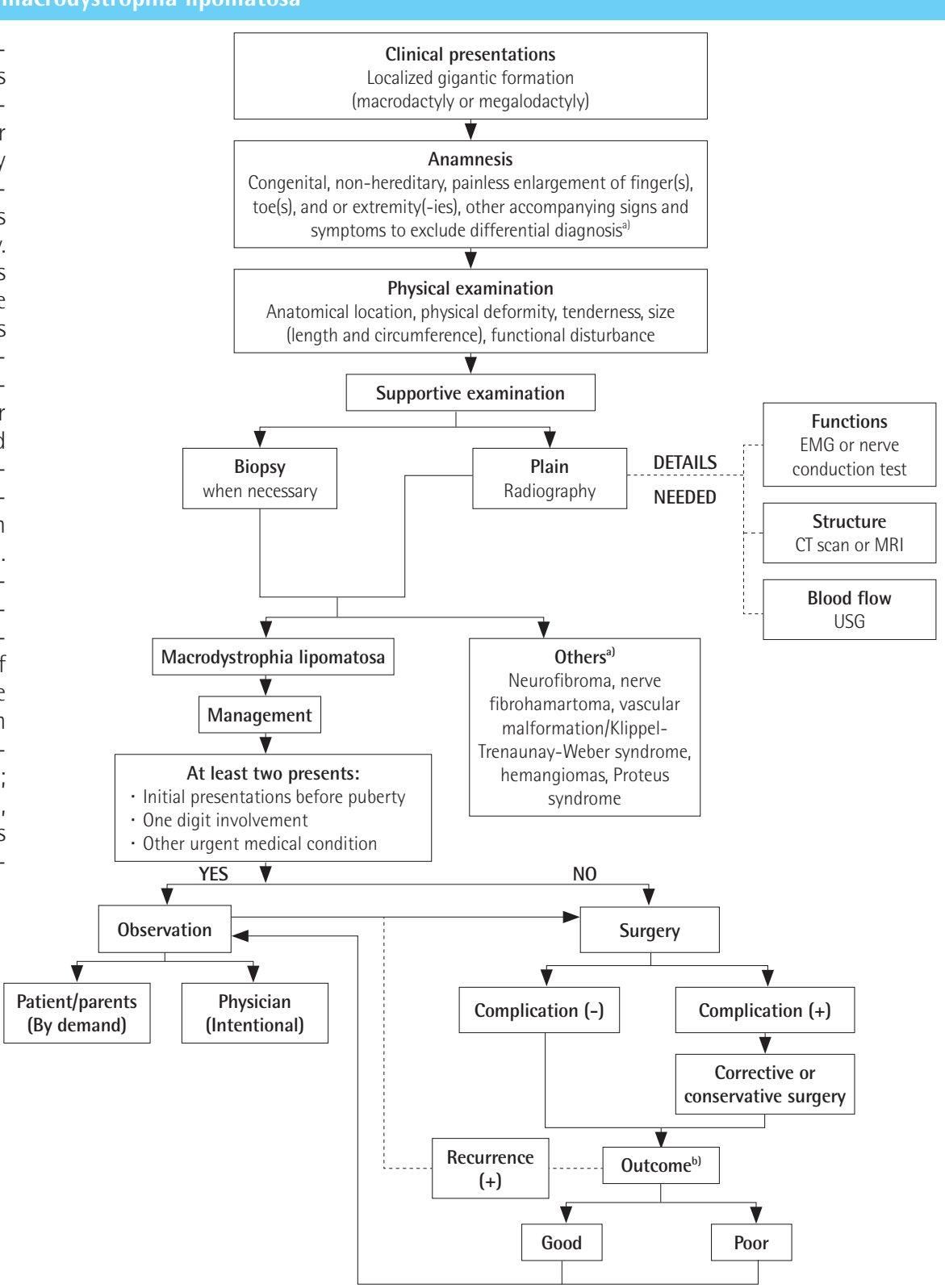

surgery in his childhood, and thus the first presenting age was actually younger. The last two cases are also younger; they presented due to cosmetic and functional difficulties. Parents might have sought treatment earlier due to the need for the affected limbs to look 'normal' before the children started school. The distribution of the affected digits in these patients is similar to the findings of the review, which were that MDL occurs in multiple adjacent digits with second digit involvement. After radiographic examinations were performed, surgery planning resulted in single-staged surgery for all patients. However, due to technical reasons during the surgery, the 6-year-old female case received treatment in a multi-staged surgical manner. Joint man- agement, rather than bony intervention, was performed by rebalancing the joint ligament. Ray amputation in the second case was performed with the consideration of removing ineffective digits to achieve better functional outcome. This decision was also in line with the findings of this review. Furthermore, from all three cases, only one patient had a complication of delayed wound healing. This can be fixed with a skin graft of the area. Impressively, all cases had positive outcomes, which might rationalize the decision of management made by the first author.

There are several limitations to this study. Level of evidence is an important aspect of this study. As it only uses case series and case reports, its evidence level is a four, the lowest level except 
for that of an expert opinion. Thus the evidence we present is not as strong as a cohort or case-control study. However, it is difficult to conduct this type of studies in surgical settings due to ethical issues. Thus, this study can be considered sufficiently relevant to be used. Other weaknesses might be a bias during article selection. Incomplete information from the article title and abstract might infer different meanings of the real condition of the patients than can be clearly shown in full-text articles. Additionally, only a single database was used to find the relevant articles. Any studies that were not indexed by the database could have been missed. In addition, the inability to add more cases from the author and new cases from journal articles due to period-related inclusion criteria, might have caused many very recent cases of MDL to be neglected and excluded from this study. In relation to the diagnosis and management of MDL, this study suggests several things. The use of non-invasive diagnostic tools should be carefully considered, according to the severity of the condition. Surgery might be a better choice of management than observation, taking into account future complications in the absence of surgery and the beneficial outcomes of surgical procedures for patients. Patients should be followed up regularly to determine the incidence of reoccurrence. Although an algorithm is proposed in this study, it has not been tested yet; its accuracy and efficiency might therefore still be questionable.

\section{REFERENCES}

1. Tahiri Y, Xu L, Kanevsky J, et al. Lipofibromatous hamartoma of the median nerve: a comprehensive review and systematic approach to evaluation, diagnosis, and treatment. J Hand Surg Am 2013;38:2055-67.

2. Sudesh P, Raj N, Kumar R, et al. Macrodystrophia lipomatosa. Foot (Edinb) 2012;22:172-4.

3. Cologlu H. A solution for surgical treatment of the combination lipofibromatous hamartoma and macrodystrophia lipomatosa: "vascularised digital nerve flap". Handchir Mikrochir Plast Chir 2013;45:39-41.

4. Center for Evidence-Based Management. Critical appraisal for a case study [Internet]. Amsterdam: Netherlands; [cited 2014 Apr 2]. Available from: http://www.cebma.org/wpcontent/uploads/critical-appraisal-question-for-a-case-study. pdf.

5. van der Meer S, Nicolai JP, Schut SM, et al. Bilateral macrodystrophia lipomatosa of the upper extremities with syndactyly and multiple lipomas. J Plast Surg Hand Surg 2011;45: 303-6.

6. Feriz H. Macrodystrophia lipomatosa progressiva. Virchows Arch Pathol Anat Physiol Clin Med 1925;260:308-68.
7. Rohilla S, Jain N, Sharma R, et al. Macrodystrophia lipomatosa involving multiple nerves. J Orthop Traumatol 2012; 13:41-5.

8. Khan RA, Wahab S, Ahmad I, et al. Macrodystrophia lipomatosa: four case reports. Ital J Pediatr 2010;36:69.

9. Kwon JH, Lim SY, Lim HS. Macrodystrophia lipomatosa. Arch Plast Surg 2013;40:270-2.

10. Pandey AK. Magnetic resonance imaging of a case of monomelic macrodystrophia lipomatosa. Australas Radiol 2007; 51 Suppl:B227-30.

11. Tuzuner T, Parlak AH, Kavak A, et al. A neglected case of macrodystrophia lipomatosa of the foot in an elderly man. J Am Podiatr Med Assoc 2005;95:486-90.

12. Barsky AJ. Macrodactyly. J Bone Joint Surg Am 1967;49: 1255-66.

13. Wang YC, Jeng CM, Marcantonio DR, et al. Macrodystrophia lipomatosa. MR imaging in three patients. Clin Imaging 1997;21:323-7.

14. Ozturk A, Baktiroglu L, Ozturk E, et al. Macrodystrophia lipomatosa: a case report. Acta Orthop Traumatol Turc 2004; 38:220-3.

15. Singla V, Virmani V, Tuli P, et al. Case Report: Macrodystrophia lipomatosa: illustration of two cases. Indian J Radiol Imaging 2008; 18:298-301.

16. D'Costa H, Hunter JD, O'Sullivan G, et al. Magnetic resonance imaging in macromelia and macrodactyly. Br J Radiol 1996;69:502-7.

17. Gupta SK, Sharma OP, Sharma SV, et al. Macrodystrophia lipomatosa: radiographic observations. Br J Radiol 1992;65: 769-73.

18. Albright SB, Wolfswinkel EM, Caceres KJ, et al. Bilateral macrodystrophia lipomatosa with syndactyly: a case report and literature review. Hand Surg 2013;18:267-72.

19. Aydos SE, Fitoz S, Bokesoy I. Macrodystrophia lipomatosa of the feet and subcutaneous lipomas. Am J Med Genet A 2003;119:63-5.

20. Yaghmai I, McKowne F, Alizadeh A. Macrodactylia fibrolipomatosis. South Med J 1976;69:1565-8.

21. Goldman AB, Kaye JJ. Macrodystrophia lipomatosa: radiographic diagnosis. AJR Am J Roentgenol 1977;128:101-5.

22. Mosby I. Mosby's medical dictionary. St. Louis, MO: Mosby; 2009.

23. Moran V, Butler F, Colville J. X-ray diagnosis of macrodystrophia lipomatosa. Br J Radiol 1984;57:523-5.

24. Di Ianni F, Di Ianni G, Isidoro C, et al. On a case of "Macrodystrophia lipomatosa”. Eur Rev Med Pharmacol Sci 1997; 1:173-6.

25. Hildebrandt JW, Olson P, Paratainen H, et al. Radiologic case 
study: Macrodystrophia lipomatosa. Orthopedics 1993;16: 1075-7.

26. Ly JQ Beall DP. Quiz case. Macrodystrophia lipomatosa. Eur J Radiol 2003;47:16-8.

27. Chiang CL, Tsai MY, Chen CK. MRI diagnosis of fibrolipomatous hamartoma of the median nerve and associated macrodystrophia lipomatosa. J Chin Med Assoc 2010;73:499502.

28. Soler R, Rodriguez E, Bargiela A, et al. MR findings of macrodystrophia lipomatosa. Clin Imaging 1997;21:135-7.

29. Blacksin M, Barnes FJ, Lyons MM. MR diagnosis of macrodystrophia lipomatosa. AJR Am J Roentgenol 1992;158: 1295-7.

30. Boren WL, Henry RE Jr, Wintch K. MR diagnosis of fibrolipomatous hamartoma of nerve: association with nerve territory-oriented macrodactyly (macrodystrophia lipomatosa). Skeletal Radiol 1995;24:296-7.

31. Turkington JR, Grey AC. MR imaging of macrodystrophia lipomatosa. Ulster Med J 2005;74:47-50.

32. Curry NS, Schabel SI, Keuper JT. Computed tomography diagnosis of macrodystrophia lipomatosa. J Comput Tomogr 1988;12:295-7.

33. Upadhyay D, Parashari UC, Khanduri S, et al. Macrodystrophia lipomatosa: radiologic-pathologic correlation. J Clin Imaging Sci 2011;1:18.

34. Viola RW, Kahn A, Pottenger LA. Paraxial macrodystrophia lipomatosa of the medial right lower limb. J Pediatr Orthop 1991;11:671-5.

35. Meyer BU, Roricht S. Fibrolipomatous hamartoma of the proximal ulnar nerve associated with macrodactyly and macrodystrophia lipomatosa as an unusual cause of cubital tunnel syndrome. J Neurol Neurosurg Psychiatry 1997;63:80810.

36. Watt AJ, Chung KC. Macrodystrophia lipomatosa: a reconstructive approach to gigantism of the foot.J Foot Ankle Surg 2004;43:51-5.

37. Ho CA, Herring JA, Ezaki M. Long-term follow-up of progressive macrodystrophia lipomatosa: a report of two cases. J Bone Joint Surg Am 2007;89:1097-102. 


\section{Appendix 1. The summary of age, gender, and anatomical location of the inclusive articles}

\begin{tabular}{|c|c|c|c|c|c|c|}
\hline No. & Author(s) & Year & No. of cases & Age (yr) & Gender & Anatomical location \\
\hline \multicolumn{7}{|c|}{ Upper extremities } \\
\hline 1 & Yesilada et al. [1] & 2013 & 1 & 42 & Male & Right upper extremity \\
\hline 2 & Kwon et al. [2] & 2013 & 1 & 14 & Male & Thumb, index, and thenar area of left hand \\
\hline 3 & Cöloğlu [3] & 2013 & 1 & 28 & Male & Fourth finger of the left hand \\
\hline 4 & van der Meer et al. [4] & 2011 & 1 & $2 \mathrm{mo}$ & Male & $\begin{array}{l}\text { Ring and little fingers of his left hand and the middle and ring fingers of the } \\
\text { right hand }\end{array}$ \\
\hline 5 & Rohilla et al. [5] & 2012 & 1 & 20 & Female & $\begin{array}{l}\text { Thumb, index and middle fingers of the left hand, lateral aspect of the left } \\
\text { hand, and the left shoulder }\end{array}$ \\
\hline 6 & Gao et al. [6] & 2010 & 1 & 14 & Female & Ring finger of the right hand and right upper extremity \\
\hline 7 & Chiang et al. [7] & 2010 & 1 & 28 & Male & Middle finger of the left hand \\
\hline 8 & Singla et al. [8] & 2008 & 1 & 2 & Male & Dorsal and palmar aspects of the fourth and fifth digits of the left hand \\
\hline 9 & Mahafza et al. [9] & 2008 & 1 & 1 & Female & Index, middle and ring fingers of the right hand \\
\hline 10 & D'Costa et al. [10] & 1996 & 1 & 34 & Male & Thumb, index finger and radial half of the right hand \\
\hline 11 & Ho et al. [11] & 2007 & 1 & 6 & Male & Index and long fingers of the left hand \\
\hline 12 & Brodwater et al. [12] & 2000 & 1 & 3 & Male & Middle finger of the left hand \\
\hline 13 & Meyer and Röricht [13] & 1997 & 1 & 35 & Female & Fourth finger \\
\hline 14 & Boren et al. [14] & 1995 & 1 & 42 & Male & Thumb of the right hand \\
\hline 15 & Pearn et al. [15] & 1983 & 1 & 12 & Male & Index finger, palm, forearm of the left side \\
\hline \multirow[t]{2}{*}{16} & Goldman and Kaye [16] & 1977 & 2 & 5 & Female & Second and third digits of the hand \\
\hline & & & & $\mathrm{N} / \mathrm{A}$ & Male & Second digit of the hand \\
\hline 17 & Ranawat et al. [17] & 1968 & 1 & 55 & Male & $\begin{array}{l}\text { Thumb, index, and long fingers of the left hand; the palm and the lower one } \\
\text { third of the left forearm }\end{array}$ \\
\hline \multicolumn{7}{|r|}{ (2) } \\
\hline 1 & Ceylan and Tuzuner [18] & 2013 & 1 & 23 & Female & Second toe of right foot \\
\hline \multirow[t]{6}{*}{2} & Sudesh et al. [19] & 2012 & 6 & 3 & Male & Second toe \\
\hline & & & & 3 & Female & Second toe \\
\hline & & & & 2 & Male & Second toe \\
\hline & & & & 4 & Male & Third toe \\
\hline & & & & 5 & Male & Second toe \\
\hline & & & & 4 & Female & Third toe \\
\hline 3 & Upadhyay et al. [20] & 2011 & 1 & 22 & Male & Second, third, and fourth toes of the left foot \\
\hline 4 & Guzoglu et al. [21] & 2012 & 1 & 1 day & Male & $\begin{array}{l}\text { Second, third, and, fourth toes of the right foot and the dorsal aspect of the } \\
\text { right foot }\end{array}$ \\
\hline 5 & Kozanoglu et al. [22] & 2008 & 1 & 48 & Male & Great toe of the right foot, right ankle and cruris \\
\hline 6 & Ho et al. [11] & 2007 & 1 & $4 \mathrm{mo}$ & Female & Second and third toes on the left foot \\
\hline 7 & Tuzuner et al. [23] & 2005 & 1 & 64 & Male & First, second, and third toes of the right foot \\
\hline 8 & Oztürk et al. [24] & 2004 & 1 & 40 & Male & First toe of the right foot \\
\hline 9 & Watt and Chung [25] & 2004 & 1 & $1 \mathrm{mo}$ & Female & Great, second, and third toes and the plantar aspect of the right foot \\
\hline 10 & Wang et al. [26] & 1997 & 1 & 10 & Female & Plantar surface of the second digit of the right foot \\
\hline 11 & Soler et al. [27] & 1997 & 1 & $8 \mathrm{mo}$ & Male & Distal ends of the second and third digits and left foot \\
\hline 12 & Viola et al. [28] & 1991 & 1 & $3 \mathrm{mo}$ & Male & $\begin{array}{l}\text { Marked hypertrophy of the first and second rays of the right foot and mild } \\
\text { hypertrophy of the entire medial portion of the right lower limb }\end{array}$ \\
\hline 13 & Bansal and Harmit [29] & 1989 & 1 & 6 & Male & Left lower limb \\
\hline 14 & Curry et al. [30] & 1988 & 1 & 52 & Female & Second and third toes of the left foot \\
\hline 15 & Baruchin et al. [31] & 1988 & 1 & 2 & Female & $\begin{array}{l}\text { Gigantism of the first, second, and third toes, with syndactyly of the second } \\
\text { and third toes }\end{array}$ \\
\hline 16 & Moran et al. [32] & 1984 & 1 & 18 & Female & Second, third and fourth toes of the left foot \\
\hline \multirow[t]{4}{*}{17} & Goldman and Kaye [16] & 1977 & 4 & $\mathrm{~N} / \mathrm{A}$ & Male & Second, third, and fourth digits of the foot \\
\hline & & & & $\mathrm{N} / \mathrm{A}$ & Male & Second and third digits of the foot \\
\hline & & & & $\mathrm{N} / \mathrm{A}$ & Male & Second digit of the foot \\
\hline & & & & 44 & Male & Fourth digit of the foot \\
\hline
\end{tabular}




\begin{tabular}{|c|c|c|c|c|c|c|c|}
\hline No. & Author(s) & Year & $\begin{array}{l}\text { No. of } \\
\text { cases }\end{array}$ & $\begin{array}{l}\text { Age } \\
(y r)\end{array}$ & $\begin{array}{l}\text { Length of } \\
\text { follow-up }\end{array}$ & $\begin{array}{c}\text { Diagnostic } \\
\text { tools }\end{array}$ & Intervention \\
\hline \multicolumn{8}{|c|}{ Upper extremities } \\
\hline 1 & $\begin{array}{l}\text { Yesilada et al. } \\
\text { [1] }\end{array}$ & 2013 & 1 & 42 & N/A & $\mathrm{N} / \mathrm{A}$ & $\begin{array}{l}\text { Amputation of the thumb } 4 \text { years ago. } \\
\text { Resection of hypertrophic carpal bone } \\
\text { and debulking of large soft tissue mass. }\end{array}$ \\
\hline 2 & Kwon et al. [2] & 2013 & 1 & 14 & $\mathrm{~N} / \mathrm{A}$ & X-ray and MRI & $\begin{array}{l}\text { Previous debulking surgery twice } \\
\text { Debulking operation of the thumb and } \\
\text { amputation of the index finger at the } \\
\text { mid-level of the mid-phalangeal bone }\end{array}$ \\
\hline 3 & Cöloğlu [3] & 2013 & 1 & 28 & $18 \mathrm{mo}$ & $\mathrm{X}$-ray and MRI & $\begin{array}{l}\text { Reconstruction of the fourth finger, } \\
\text { intraneural fascicular dissection and } \\
\text { limited excision of the ulnar nerve with } \\
\text { extension to the digital nerve of the ring } \\
\text { finger. }\end{array}$ \\
\hline 4 & $\begin{array}{l}\text { van der Meer } \\
\text { et al. [4] }\end{array}$ & 2011 & 1 & $2 \mathrm{mo}$ & $42 \mathrm{yr}$ & X-ray & $\begin{array}{l}\text { 12-years-old: amputation of the 4th and } \\
5 \text { th ray of the left hand and removal of } \\
\text { lipoma. }\end{array}$ \\
\hline
\end{tabular}

5 Rohilla et al. [5] $2012 \quad 1 \quad 20 \quad$ N/A $\quad$ X-ray and MP

6 Gao et al. [6] $2010 \quad 1 \quad 14 \quad 18$ mo $\quad$ X-ray and MRl

$\begin{array}{llllll}7 & \text { Chiang et al. [7] } 2010 & 1 & 28 & \text { N/A } & \begin{array}{l}\text { X-ray, MRI, and } \\ \text { nerve conduction } \\ \text { study }\end{array}\end{array}$

8 Singla et al. [8] $2008 \quad 1 \quad 2 \quad$ N/A $\quad$ X-ray and MR

9 Mahafza et al. $2008 \quad 1 \quad 1 \quad$ N/A $\quad$ X-ray, MRI, and [9]

10 D'Costa et al. 2007 [10]

11 Ho et al. [11] $2007 \quad 1 \quad 6 \quad 3$ yr $\quad$ Serial X-rays

12 Brodwater et al. $2000 \quad 1 \quad 3 \quad>2 y r \quad$ Serial MRl [12]

\begin{tabular}{|c|c|c|c|c|c|c|c|}
\hline 13 & $\begin{array}{l}\text { Meyer and } \\
\text { Röricht [13] }\end{array}$ & 1997 & 1 & 35 & $\mathrm{~N} / \mathrm{A}$ & $\begin{array}{r}\text { MRI, EMG, and nerve } \\
\text { conduction studies }\end{array}$ & $\begin{array}{l}\text { 3-years-old: amputation of the fourth } \\
\text { finger }\end{array}$ \\
\hline 14 & Boren et al. [14] & 1995 & 1 & 42 & $\mathrm{~N} / \mathrm{A}$ & X-ray and MRI & $\begin{array}{l}\text { Bone and soft tissue reduction in the } \\
\text { thumb and carpal tunnel release }\end{array}$ \\
\hline 15 & Pearn et al. [15] & 1983 & 1 & 12 & $\mathrm{~N} / \mathrm{A}$ & Not stated & Observation until puberty \\
\hline 16 & $\begin{array}{l}\text { Goldman and } \\
\text { Kaye [16] }\end{array}$ & 1977 & 2 & $\begin{array}{r}5 \\
N / A\end{array}$ & $\begin{array}{l}7 \mathrm{yr} \\
\mathrm{N} / \mathrm{A}\end{array}$ & $\begin{array}{l}\text { Serial X-rays } \\
\text { X-ray }\end{array}$ & $\begin{array}{l}\text { Debulking } \\
\text { Unknown surgery }\end{array}$ \\
\hline
\end{tabular}

\section{Debulking and partial amputation of the overgrown digits (middle phalanges of the 2nd and 3rd digits) with preservation of distal phalanges. \\ Debulking of the right upper limb, amputation of the right ring finger and the little finger \\ 4-years-old: amputation of the middle finger for cosmetic reasons. 25-years- old: median nerve release.}

Debulking and reconstruction of the fingers

Debulking and release of syndactyly electrophysiologic exam

N/A

Amputation of the right thumb and debulking of the palm

6-years-old: amputation of the index and N/A middle digits with shortening of the radial digital nerve to the ring finger and reconstruction of the ulnar digital nerve to the thumb with use of the dorsal radial sensory branch.

9-years-old: decline surgery

Exploration of the lesion and debulk for None cosmetic reasons with open investigation release with neurolysis of the median nerve and radial and ulnar digital nerves of the middle finger with excision of the adjacent excess fatty tissue.

N/A of the median nerve. A carpal-tunnel

\begin{tabular}{|c|c|}
\hline \multirow{2}{*}{$\begin{array}{l}\text { Compli- } \\
\text { cations }\end{array}$} & Outcome \\
\hline & Esthetic Functional \\
\hline
\end{tabular}

N/A

N/A Unspecified improvement

Some degree of Unsatisfied Significant sensory loss improvement in the first web space

None

Satisfied Fair improvement N/A

N/A Left $=$ unspecified improvement, Right $=$ no

improvement

N/A N/A

None

4 yo: numbness

sensation over

the palm. 25

yo: recurrent symptoms

$\begin{array}{lll}\text { N/A } & \text { N/A } & \text { N/A } \\ \text { N/A } & \text { N/A } & \text { N/A } \\ \text { N/A } & \text { N/A } & \text { N/A } \\ \text { N/A } & \text { Fair } \\ & & \\ & & \\ & & \end{array}$

N/A N/A improvement

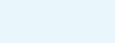

N/A N/A

$\begin{array}{lcl}\text { N/A } & \text { N/A } & \text { N/A } \\ \text { N/A } & \text { N/A } & \text { N/A } \\ \text { Not applicable } & \text { Not } & \text { Not applicable } \\ & \text { applicable } \\ \text { N/A } & \text { N/A } & \text { N/A } \\ \text { N/A } & \text { N/A } & \text { N/A }\end{array}$




\section{Appendix 2. Continued}

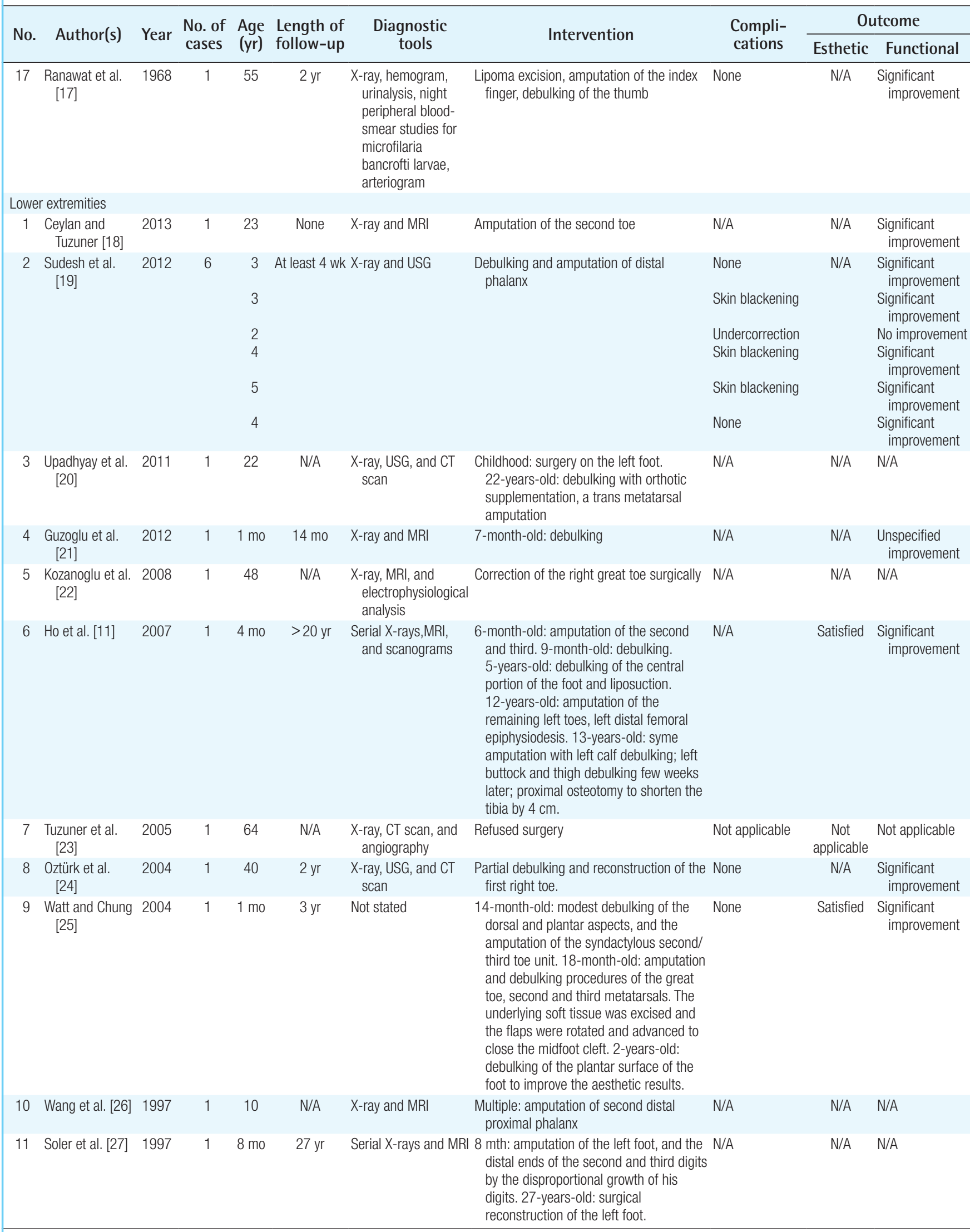




\section{Appendix 2. Continued}

\begin{tabular}{|c|c|c|c|c|c|c|c|c|c|c|}
\hline \multirow{2}{*}{ No. } & \multirow{2}{*}{ Author(s) } & \multirow{2}{*}{ Year } & \multirow{2}{*}{$\begin{array}{l}\text { No. of } \\
\text { cases }\end{array}$} & \multirow{2}{*}{$\begin{array}{l}\text { Age } \\
\text { (yr) }\end{array}$} & \multirow{2}{*}{$\begin{array}{l}\text { Length of } \\
\text { follow-up }\end{array}$} & \multirow{2}{*}{$\begin{array}{l}\text { Diagnostic } \\
\text { tools }\end{array}$} & \multirow{2}{*}{ Intervention } & \multirow{2}{*}{$\begin{array}{l}\text { Compli- } \\
\text { cations }\end{array}$} & \multicolumn{2}{|c|}{ Outcome } \\
\hline & & & & & & & & & Esthetic & Functional \\
\hline 12 & Viola et al. [28] & 1991 & 1 & $3 \mathrm{mo}$ & $10 \mathrm{yr}$ & $\begin{array}{l}\text { X-rays, serial } \\
\text { laboratory } \\
\text { examination, renal } \\
\text { USG, IV urograms, } \\
\text { arteriography of the } \\
\text { lower limbs and } \\
\text { kidneys, and } 13 \\
\text { bone age analysis }\end{array}$ & $\begin{array}{l}\text { First year: thinning and shortening } \\
\text { osteotomies of the } 1 \text { st and 2nd proximal } \\
\text { phalanges and corresponding } \\
\text { metatarsals, debulking of the entire } \\
\text { medial foot, and a } 30 \text { varus osteotomy } \\
\text { of the distal tibia. Second year: distal } \\
\text { femoral varus osteotomy, debulking of } \\
\text { the groin to the medial malleolus, and a } \\
\text { distal tibialvarus shortening osteotomy } \\
\text { with excision of the lateral third of the } \\
\text { Achilles tendon and release of the lateral } \\
\text { ankle ligaments. 2-years } 7 \text {-month-old: } \\
\text { amputation of the first and second toes. } \\
\text { 3-years 8-month old: syme amputation. } \\
\text { 5-years-old: distal femoral and proximal } \\
\text { tibial epiphyseal closing wedge } \\
\text { osteotomies. 9-years-old: a varus } \\
\text { subtrochanteric osteotomy surgery and } \\
\text { liposuction of the proximal medial right } \\
\text { lower limb (395 g mature adipose } \\
\text { tissue). }\end{array}$ & None & $\mathrm{N} / \mathrm{A}$ & $\begin{array}{l}\text { Significant } \\
\text { improvement }\end{array}$ \\
\hline 13 & $\begin{array}{l}\text { Bansal and } \\
\text { Harmit [29] }\end{array}$ & 1989 & 1 & 6 & $3 \mathrm{yr}$ & X-ray & A mid-thigh amputation & None & N/A & $\begin{array}{l}\text { Fair } \\
\text { improvement }\end{array}$ \\
\hline 14 & Curry et al. [30] & 1988 & 1 & 52 & None & $\mathrm{X}$-ray and CT scan & $\begin{array}{l}\text { Amputation of the distal portion of the } \\
\text { second toe }\end{array}$ & $\mathrm{N} / \mathrm{A}$ & N/A & $\mathrm{N} / \mathrm{A}$ \\
\hline 15 & $\begin{array}{l}\text { Baruchin et al. } \\
\text { [31] }\end{array}$ & 1988 & 1 & 2 & $1 \mathrm{yr}$ & $\mathrm{X}$-ray & $\begin{array}{l}\text { Debulking and removal of the } \\
\text { hypertrophied toes, with ephysiodesis of } \\
\text { the metatarsals }\end{array}$ & None & $\mathrm{N} / \mathrm{A}$ & $\begin{array}{l}\text { Significant } \\
\text { improvement }\end{array}$ \\
\hline 16 & $\begin{array}{l}\text { Moran et al. } \\
\text { [32] }\end{array}$ & 1984 & 1 & 18 & N/A & X-ray & $\begin{array}{l}\text { 1-year-old: amputation of the terminal } \\
\text { phalanx of the third toe and osteotomy } \\
\text { of the proximal phalanx of the second } \\
\text { toe. }\end{array}$ & $\mathrm{N} / \mathrm{A}$ & $\mathrm{N} / \mathrm{A}$ & $\mathrm{N} / \mathrm{A}$ \\
\hline 17 & $\begin{array}{l}\text { Goldman and } \\
\text { Kaye [16] }\end{array}$ & 1977 & 4 & $\begin{array}{l}N / A \\
N / A \\
N / A \\
44\end{array}$ & $\begin{array}{l}\text { N/A } \\
\text { N/A } \\
\text { N/A } \\
\text { N/A }\end{array}$ & $\begin{array}{l}\text { X-ray } \\
\text { X-ray } \\
\text { X-ray } \\
\text { X-ray }\end{array}$ & $\begin{array}{l}\text { Unknown surgery } \\
\text { Unknown surgery } \\
\text { Unknown surgery } \\
\text { Observation }\end{array}$ & $\begin{array}{l}\text { N/A } \\
\text { N/A } \\
\text { N/A } \\
\text { Not applicable }\end{array}$ & $\begin{array}{c}\mathrm{N} / \mathrm{A} \\
\mathrm{N} / \mathrm{A} \\
\mathrm{N} / \mathrm{A} \\
\text { Not } \\
\text { applicable }\end{array}$ & $\begin{array}{l}\text { N/A } \\
\text { N/A } \\
\text { N/A } \\
\text { Not applicable }\end{array}$ \\
\hline
\end{tabular}




\section{Appendix 3. Digital presentation of Macrodystrophia lipomatosa in upper extremity}

\begin{tabular}{|c|c|c|c|c|c|c|c|c|}
\hline & Authors & 1 & 2 & 3 & 4 & 5 & Addition & Side \\
\hline 1 & Yesilada et al. [1] & \multicolumn{4}{|c|}{ Upper extremity } & & & $\mathrm{R}$ \\
\hline 2 & Albright et al. [33] & \multicolumn{4}{|c|}{ Upper extremity } & & & B \\
\hline 3 & Kwon et al. [2] & + & + & - & - & - & Thenar & L \\
\hline 4 & Cöloğlu [3] & - & - & - & + & - & - & L \\
\hline \multirow[t]{2}{*}{5} & van der Meer et al. [4] & - & - & - & + & + & - & LB \\
\hline & & - & - & + & + & - & - & $\mathrm{RB}$ \\
\hline 6 & Rohilla et al. [5] & + & + & + & - & - & Shoulder & L \\
\hline 7 & Gao et al. [6] & - & - & - & + & - & Upper extremities & $\mathrm{R}$ \\
\hline 8 & Chiang et al. [7] & - & - & + & - & - & - & L \\
\hline \multirow[t]{2}{*}{9} & Singla et al. [8] & - & - & - & + & + & - & L \\
\hline & & + & + & - & - & - & - & $\mathrm{R}$ \\
\hline 10 & Dillman and Strouse [34] & - & + & + & - & - & - & L \\
\hline 11 & Mahafza et al. [9] & - & + & + & + & - & - & $\mathrm{R}$ \\
\hline 12 & D'Costa et al. [10] & + & + & - & - & - & - & $\mathrm{R}$ \\
\hline 13 & Ho et al. [11] & - & + & + & - & - & - & L \\
\hline 14 & Turkington and Grey [35] & + & - & - & - & - & - & $\mathrm{R}$ \\
\hline 15 & Sone et al. [36] & \multirow{2}{*}{\multicolumn{4}{|c|}{$\begin{array}{l}\text { Hand and forearm } \\
\text { Hand and forearm }\end{array}$}} & & & $\mathrm{N} / \mathrm{A}$ \\
\hline & & & & & & & & $\mathrm{N} / \mathrm{A}$ \\
\hline 16 & Brodwater et al. [12] & - & - & + & - & - & - & L \\
\hline 17 & Di lanni et al. [37] & + & + & + & - & - & Forearm & $\mathrm{R}$ \\
\hline 18 & Meyer and Röricht [13] & - & - & - & + & - & - & N/A \\
\hline 19 & Wang et al. [26] & \multicolumn{4}{|c|}{ Forearm } & & & $\mathrm{R}$ \\
\hline 20 & D'Costa et al. [38] & \multicolumn{4}{|c|}{ Hand } & & & $\mathrm{R}$ \\
\hline 21 & Loro et al. [39] & \multicolumn{4}{|c|}{ Hand } & & & L \\
\hline 22 & Boren et al. [14] & + & - & - & - & - & - & $\mathrm{R}$ \\
\hline 23 & Hildebrandt et al. [40] & \multicolumn{4}{|c|}{ Wrist and Hand } & & & $\mathrm{R}$ \\
\hline 24 & Jain et al. [41] & \multicolumn{4}{|c|}{ Upper limb and shoulder } & & & $\mathrm{R}$ \\
\hline 25 & Blacksin et al. [42] & - & + & - & - & - & Upper arm & $\mathrm{R}$ \\
\hline 26 & Pearn et al. [15] & - & + & - & - & - & Forearm & L \\
\hline 27 & Laval-Jeantet et al. [43] & + & + & - & - & - & - & $L$ \\
\hline \multirow[t]{2}{*}{28} & Goldman and Kaye [16] & - & + & + & - & - & - & $\mathrm{N} / \mathrm{A}$ \\
\hline & & - & + & - & - & - & - & $\mathrm{N} / \mathrm{A}$ \\
\hline \multirow[t]{3}{*}{29} & Yaghmai et al. [44] & \multicolumn{4}{|c|}{ Hand } & & - & L \\
\hline & & \multicolumn{4}{|c|}{ Hand } & & - & $\mathrm{L}$ \\
\hline & & \multicolumn{4}{|c|}{ Hand } & & - & $\mathrm{R}$ \\
\hline 30 & Ranawat et al. [17] & + & + & + & - & - & Forearm & L \\
\hline \multirow[t]{2}{*}{31} & Prasetyono TOH, Hanafi E, Astriana Wa) & + & + & - & - & - & Thenar & $\mathrm{R}$ \\
\hline & & 11 & 16 & 10 & 7 & 2 & & $15 \mathrm{R}, 14 \mathrm{~L}, 2 \mathrm{~B}, 5 \mathrm{~N} / \mathrm{A}$ \\
\hline
\end{tabular}




\section{Appendix 4. Digital presentation of macrodystrophia lipomatosa in lower extremity}

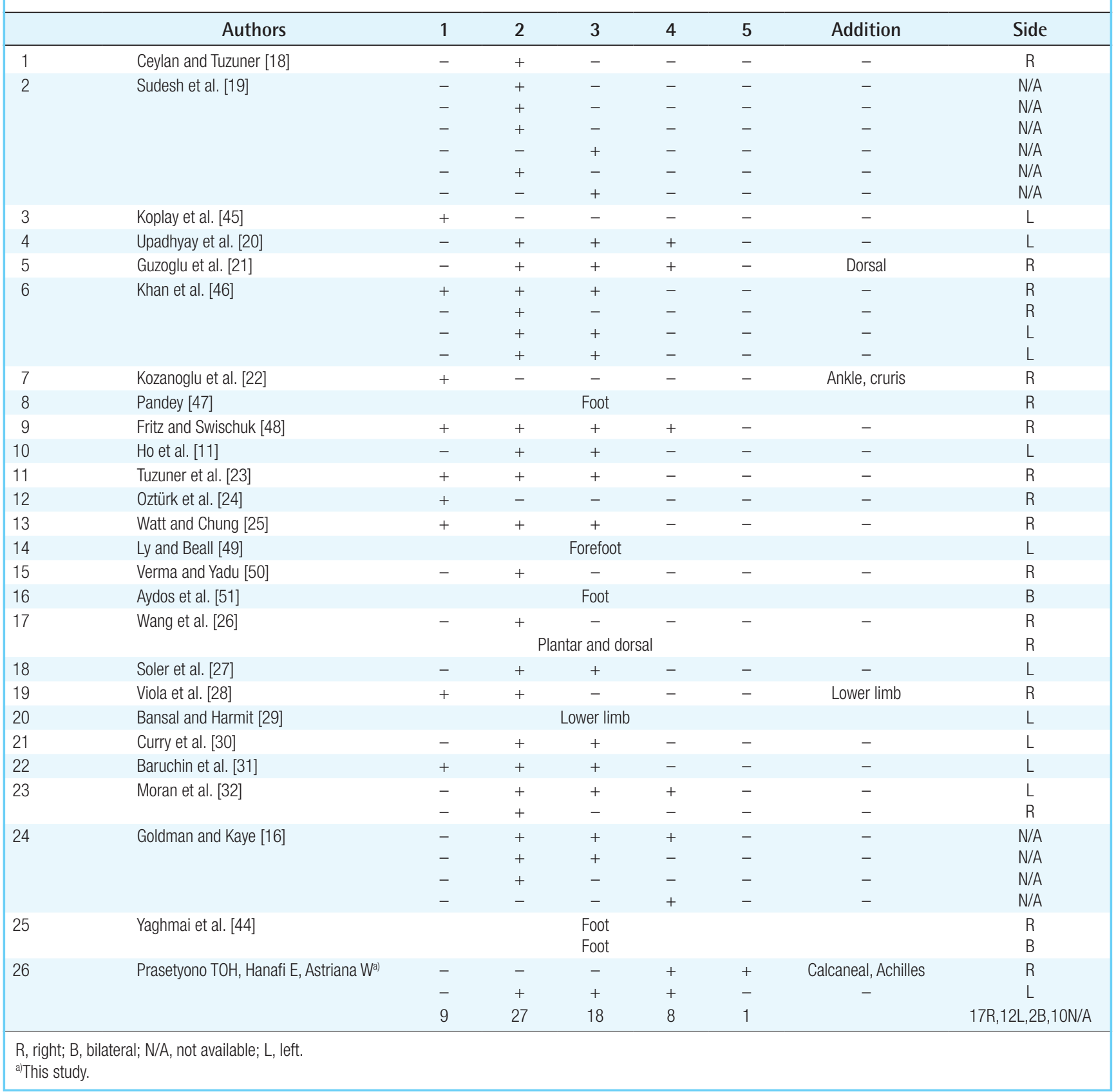




\section{APPENDIX REFERENCES}

1. Yesilada AK, Sevim KZ, Sucu DO, et al. Combined triggering at the wrist and fingers and severe carpal tunnel syndrome caused by macrodystrophia lipomatosa: case report and review of literature. Acta Chir Plast 2013;55:23-5.

2. Kwon JH, Lim SY, Lim HS. Macrodystrophia lipomatosa. Arch Plast Surg 2013;40:270-2.

3. Cologlu H. A solution for surgical treatment of the combination lipofibromatous hamartoma and macrodystrophia lipomatosa: "vascularised digital nerve flap". Handchir Mikrochir Plast Chir 2013;45:39-41.

4. van der Meer S, Nicolai JP, Schut SM, et al. Bilateral macrodystrophia lipomatosa of the upper extremities with syndactyly and multiple lipomas. J Plast Surg Hand Surg 2011;45: 303-6.

5. Rohilla S, Jain N, Sharma R, et al. Macrodystrophia lipomatosa involving multiple nerves. J Orthop Traumatol 2012; $13: 41-5$.

6. Gao B, Zheng LP, Cai ZD. Limb salvage surgery in a patient with macrodystrophia lipomatosa involving an entire upper extremity. Chin Med J (Engl) 2010;123:2744-7.

7. Chiang CL, Tsai MY, Chen CK. MRI diagnosis of fibrolipomatous hamartoma of the median nerve and associated macrodystrophia lipomatosa. J Chin Med Assoc 2010;73:499502.

8. Singla V, Virmani V, Tuli P, et al. Case Report: Macrodystrophia lipomatosa: Illustration of two cases. Indian J Radiol Imaging 2008;18:298-301.

9. Mahafza WS, Haroun AA, Abdul-Wahab AD, et al. Macrodystrophia lipomatosa with syndactyly. Saudi Med J 2008; 29:1194-6.

10. D'Costa GF, Taksande RV, Pandya BS, et al. Macrodystrophia lipomatosa: a case report. Indian J Pathol Microbiol 2007; 50:572-4.

11. Ho CA, Herring JA, Ezaki M. Long-term follow-up of progressive macrodystrophia lipomatosa: a report of two cases. J Bone Joint Surg Am 2007;89:1097-102.

12. Brodwater BK, Major NM, Goldner RD, et al. Macrodystrophia lipomatosa with associated fibrolipomatous hamartoma of the median nerve. Pediatr Surg Int 2000;16:216-8.

13. Meyer BU, Roricht S. Fibrolipomatous hamartoma of the proximal ulnar nerve associated with macrodactyly and macrodystrophia lipomatosa as an unusual cause of cubital tunnel syndrome. J Neurol Neurosurg Psychiatry 1997;63:80810.

14. Boren WL, Henry RE Jr, Wintch K. MR diagnosis of fibrolipomatous hamartoma of nerve: association with nerve terri- tory-oriented macrodactyly (macrodystrophia lipomatosa). Skeletal Radiol 1995;24:296-7.

15. Pearn J, Viljoen D, Beighton P. Limb overgrowth: clinical observations and nosological considerations. S Afr Med J 1983;64:905-8.

16. Goldman AB, Kaye JJ. Macrodystrophia lipomatosa: radiographic diagnosis. AJR Am J Roentgenol 1977;128:101-5.

17. Ranawat CS, Arora MM, Singh RG. Macrodystrophia lipomatosa with carpal-tunnel syndrome: a case report. J Bone Joint Surg Am 1968;50:1242-4.

18. Ceylan HH, Tuzuner T. Macrodystrophia lipomatosa; local gigantism. Postgrad Med J 2013;89:547-8.

19. Sudesh P, Raj N, Kumar R, et al. Macrodystrophia lipomatosa. Foot (Edinb) 2012;22:172-4.

20. Upadhyay D, Parashari UC, Khanduri S, et al. Macrodystrophia lipomatosa: radiologic-pathologic correlation. J Clin Imaging Sci 2011;1:18.

21. Guzoglu N, Gokmen T, Oguz SS, et al. Isolated macrodystrophia lipomatosa of the foot in a neonate: a case report. Clin Dysmorphol 2012;21:53-5.

22. Kozanoglu E, Koc F, Goncu K. Macrodystrophia lipomatosa with multiple entrapment neuropathies: a case report. Int J Neurosci 2008; 118:545-53.

23. Tuzuner T, Parlak AH, Kavak A, et al. A neglected case of macrodystrophia lipomatosa of the foot in an elderly man. J Am Podiatr Med Assoc 2005;95:486-90.

24. Ozturk A, Baktiroglu L, Ozturk E, et al. Macrodystrophia lipomatosa: a case report. Acta Orthop Traumatol Turc 2004; 38:220-3.

25. Watt AJ, Chung KC. Macrodystrophia lipomatosa: a reconstructive approach to gigantism of the foot. J Foot Ankle Surg 2004;43:51-5.

26. Wang YC, Jeng CM, Marcantonio DR, et al. Macrodystrophia lipomatosa: MR imaging in three patients. Clin Imaging 1997;21:323-7.

27. Soler R, Rodriguez E, Bargiela A, et al. MR findings of macrodystrophia lipomatosa. Clin Imaging 1997;21:135-7.

28. Viola RW, Kahn A, Pottenger LA. Paraxial macrodystrophia lipomatosa of the medial right lower limb. J Pediatr Orthop 1991;11:671-5.

29. Bansal VP, Harmit S. Monomelic macrodystrophia lipomatosa: a case report. Int Orthop 1989;13:77-9.

30. Curry NS, Schabel SI, Keuper JT. Computed tomography diagnosis of macrodystrophia lipomatosa. J Comput Tomogr 1988;12:295-7.

31. Baruchin AM, Herold ZH, Shmueli G, et al. Macrodystrophia lipomatosa of the foot. J Pediatr Surg 1988;23:192-4.

32. Moran V, Butler F, Colville J. X-ray diagnosis of macrodys- 
trophia lipomatosa. Br J Radiol 1984;57:523-5.

33. Albright SB, Wolfswinkel EM, Caceres KJ, et al. Bilateral macrodystrophia lipomatosa with syndactyly: a case report and literature review. Hand Surg 2013;18:267-72.

34. Dillman JR, Strouse PJ. Macrodystrophia lipomatosa. Pediatr Radiol 2010;40:372.

35. Turkington JR, Grey AC. MR imaging of macrodystrophia lipomatosa. Ulster Med J 2005;74:47-50.

36. Sone M, Ehara S, Tamakawa Y, et al. Macrodystrophia lipomatosa: CT and MR findings. Radiat Med 2000;18:129-32.

37. Di Ianni F, Di Ianni G, Isidoro C, et al. On a case of "Macrodystrophia lipomatosa”. Eur Rev Med Pharmacol Sci 1997; 1:173-6.

38. D'Costa H, Hunter JD, O'Sullivan G, et al. Magnetic resonance imaging in macromelia and macrodactyly. Br J Radiol 1996;69:502-7.

39. Loro A, Francechi F, Dal Lago A. Macrodystrophia lipomatosa: a case report. Ethiop Med J 1995;33:187-92.

40. Hildebrandt JW, Olson P, Paratainen H, et al. Radiologic case study. Macrodystrophia lipomatosa. Orthopedics 1993; 16:1075-7.

41. Jain R, Sawhney S, Berry M. CT diagnosis of macrodystrophia lipomatosa: a case report. Acta Radiol 1992;33:554-5.

42. Blacksin M, Barnes FJ, Lyons MM. MR diagnosis of macro- dystrophia lipomatosa. AJR Am J Roentgenol 1992;158: 1295-7.

43. Laval-Jeantet M, Civatte J, Vadrot D, et al. Macrodystrophia lipomatosa: angiographic aspects (author's transl). J Radiol 1979;60:653-6.

44. Yaghmai I, McKowne F, Alizadeh A. Macrodactylia fibrolipomatosis. South Med J 1976;69:1565-8.

45. Koplay M, Kantarci M, Kilinc G. Medical image. Macrodystrophia lipomatosa: multidetector CT and MRI findings. N Z Med J 2012;125:104-5.

46. Khan RA, Wahab S, Ahmad I, et al. Macrodystrophia lipomatosa: four case reports. Ital J Pediatr 2010;36:69.

47. Pandey AK. Magnetic resonance imaging of a case of monomelic macrodystrophia lipomatosa. Australas Radiol 2007; 51 Suppl:B227-30.

48. Fritz TR, Swischuk LE. Macrodystrophia lipomatosa extending into the upper abdomen. Pediatr Radiol 2007;37:1275-7.

49. Ly JQ Beall DP. Quiz case: macrodystrophia lipomatosa. Eur J Radiol 2003;47:16-8.

50. Verma A, Yadu S. Macrodystrophia lipomatosa. Indian Pediatr 2003;40:363-4.

51. Aydos SE, Fitoz S, Bokesoy I. Macrodystrophia lipomatosa of the feet and subcutaneous lipomas. Am J Med Genet A 2003;119:63-5. 